\title{
Drivers of virtual interfirm integration and its impact on performance in international customer-supplier relationships
}

Dol:

10.1007/s11575-018-0344-4

\section{Document Version}

Accepted author manuscript

Link to publication record in Manchester Research Explorer

Citation for published version (APA):

Kim, D., Jean, R-J. B., \& Sinkovics, R. R. (2018). Drivers of virtual interfirm integration and its impact on performance in international customer-supplier relationships. Management International Review, 58(3), 495-522. https://doi.org/10.1007/s11575-018-0344-4

\section{Published in:}

Management International Review

\section{Citing this paper}

Please note that where the full-text provided on Manchester Research Explorer is the Author Accepted Manuscript or Proof version this may differ from the final Published version. If citing, it is advised that you check and use the publisher's definitive version.

\section{General rights}

Copyright and moral rights for the publications made accessible in the Research Explorer are retained by the authors and/or other copyright owners and it is a condition of accessing publications that users recognise and abide by the legal requirements associated with these rights.

\section{Takedown policy}

If you believe that this document breaches copyright please refer to the University of Manchester's Takedown Procedures [http://man.ac.uk/04Y6Bo] or contact uml.scholarlycommunications@manchester.ac.uk providing relevant details, so we can investigate your claim.

\section{OPEN ACCESS}




\title{
Drivers of Virtual Interfirm Integration and its Impact on Performance in International Customer-Supplier Relationships
}

\author{
Daekwan Kim・ Ruey-Jer 'Bryan’ Jean • Rudolf R. Sinkovics
}

This is a pre-print / an Author's Original Manuscript (AAM) of an article published by Springer in Management International Review. Please cite the published article:

Kim, Daekwan, Ruey-Jer Jean, and Rudolf R. Sinkovics (2018), "Drivers of virtual interfirm integration and its impact on performance in international customer-supplier relationships," Management International Review, 58 (3), 495-522. https://doi.org/10.1007/s11575-018-0344-4

$$
\begin{gathered}
\underline{\text { Daekwan Kim }} \\
\text { Florida State University } \\
\text { Department of Marketing, College of Business } \\
\text { Tallahassee, FL 32306-1110 } \\
\text { Phone: +1 (850) 644-7890 } \\
\text { dkim@business.fsu.edu } \\
\text { http://orcid.org/0000-0003-3427-2410 } \\
\text { Ruey-Jer "Bryan" Jean } \\
\text { National Chengchi University } \\
\text { 64, Sec.2 Zhi-Nan Road, Taipei, 11605, Taiwan } \\
\text { Phone: +886 (2) 29393091 88180 } \\
\text { bryan@nccu.edu.tw } \\
\text { http://orcid.org/0000-0003-2461-7454 } \\
\text { Rudolf R. Sinkovics }
\end{gathered}
$$

The University of Manchester, Alliance Manchester Business School

Booth Street West, Manchester M15 6PB, UK.

Phone: +44 (161) 3068980

Rudolf.Sinkovics@manchester.ac.uk

http://www.manchester.ac.uk/research/rudolf.sinkovics

http://orcid.org/0000-0002-4471-5054

and

Lappeenranta University of Technology

Skinnarilankatu 34, PL 20, 53851 Lappeenranta, Finland and

Temple University, Fox School of Business, Department of Strategic Management

Philadelphia, Pennsylvania, U.S.A. 


\begin{abstract}
Consensus exists suggesting that advances in information and communication technologies are a major driver in restructuring Multinational Enterprises (MNEs) and their cross-border supply chain activities. However, the role of virtual interfirm integration and its antecedents, contingency conditions and its association with performance in international exchange relationship is not clearly specified. This study proposes that virtual interfirm integration can serve as an alternative governance mechanism for suppliers. Thus, we examine its drivers, moderators, and performance outcomes in international exchange relationships in the context of suppliers and their MNE customers. The empirical context is a study of 240 Taiwanese-based electronics equipment manufacturers. We explore the effect of communication culture, internal, inter-organizational, and environmental dimensions on virtual interfirm integration, and supplier performance in international exchange. We conclude by sharing our findings on the pertinence of virtual interfirm integration in the supplier-MNE buyer relationships.
\end{abstract}

\title{
Keywords
}

Information technology (IT); global supply chain; virtual integration; Multinational enterprise (MNE); communication culture; buyer-supplier relationship.

\section{Author note}

Correspondence should be addressed to Rudolf Sinkovics, The University of Manchester, Alliance Manchester Business School, Booth Street West, Manchester M15 6PB, United Kingdom. Email: Rudolf.Sinkovics@manchester.ac.uk, Web: www.manchester.ac.uk/research/rudolf.sinkovics

\section{Acknowledgements}

We gratefully acknowledge insightful comments received from Mo Yamin, Noemi Sinkovics and Ram Mudambi during seminars at The University of Manchester, Alliance Manchester Business School, UK and Fox School of Business, Temple University, Philadelphia, USA.

\section{Biographic notes}

Daekwan Kim (PhD, Michigan State University), is an Professor of Marketing and International Business in the College of Business at Florida State University. His research is on the impact of IT on firm marketing strategies and activities, marketing/international marketing strategies, and international buyer-seller relationships. Email: dkim@business.fsu.edu

Ruey-Jer "Bryan" Jean (PhD, The University of Manchester), is Professor of International Business at the Department of International Business, National Chengchi University, Taiwan. 
His research focuses on inter-organizational relationship management and international new ventures in digital and data rich environments, with a focus on emerging markets. He was born in Taiwan and lives in Taipei. Email: bryan@nccu.edu.tw

Rudolf R. Sinkovics (PhD, WU Vienna), is Professor of International Business at The University of Manchester, UK, Visiting Professor at Lappeenranta University of Technology, Finland and Visiting Scholar at Fox School of Business, Temple University. He has published on inter-organizational governance, the role of ICT in firm internationalization, and currently works on rising powers, and responsible business. Email: $\underline{\text { Rudolf.Sinkovics@manchester.ac.uk }}$

\section{Manuscript information}

Manuscript submitted: July 2016

First Revision, May 2017

Second Revision, November 2017

Third Revision, January 2018

Accepted, January 2018 


\title{
Drivers of Virtual Interfirm Integration and its Impact on Performance in International Customer-Supplier Relationships
}

\begin{abstract}
Consensus exists suggesting that advances in information and communication technologies are a major driver in restructuring Multinational Enterprises (MNEs) and their cross-border supply chain activities. However, the role of virtual interfirm integration and its antecedents, contingency conditions and its association with performance in international exchange relationship is not clearly specified. This study proposes that virtual interfirm integration can serve as an alternative governance mechanism for suppliers. Thus, we examine its drivers, moderators, and performance outcomes in international exchange relationships in the context of suppliers and their MNE customers. The empirical context is a study of 240 Taiwanese-based electronics equipment manufacturers. We explore the effect of communication culture, internal, inter-organizational, and environmental dimensions on virtual interfirm integration, and supplier performance in international exchange. We conclude by sharing our findings on the pertinence of virtual interfirm integration in the supplier-MNE buyer relationships.
\end{abstract}

\section{Keywords}

Information technology (IT); global supply chain; virtual integration; Multinational enterprise (MNE); communication culture; buyer-supplier relationship. 


\section{Drivers of Virtual Interfirm Integration and its Impact on Performance in International Customer-Supplier Relationships}

\section{Introduction and motivation}

Changes in the landscape of international business, specifically key globalization dynamics such as outsourcing and advances in information technologies (IT), have facilitated shifts in the strategy and structure of multinational enterprises (MNEs). An increasing emphasis focuses on specialized "slivers" of activities, i.e. disintegrating and stretching value-adding activities of MNEs with global suppliers (Buckley and Ghauri 2004). For example, established multinational companies such as Dell, GM, and Wal-Mart have derisked their operating model and ceded control of foreign manufacturing to contracting suppliers that continue to work closely with them to produce their brand products. The advance of IT and modern supply chain management systems (SCMs) has led to MNEs building virtual connectivity and improve coordination with their suppliers in dynamic markets (M. Subramani 2004).

In line with this trend, the issues concerning IT development in shaping global supply chains have increasingly captured scholarly attention. The extant literature contends that IT advances have been a major driver in restructuring MNEs and their operations of global supply chains (Birkinshaw et al. 2001; Nolan et al. 2002). This is due to its effect of enhanced efficient coordination and communication within and across organizational boundaries. Virtual interfirm integration (Zaheer and Venkatraman 1994) -- a specific form of quasiintegration achieved through the deployment of specific information systems between supply chain partners -- has assumed a key role in information systems (e.g.Wang et al. 2006) and operations management literature (e.g. Daekwan Kim et al. 2006). Virtual interfirm integration differs significantly from vertical integration in traditional organizations in that supply chain partners are integrated via information flows rather than ownership. Our objective is to add to the existing stock of knowledge on virtual interfirm integration in global supply chains by investigating a number of issues that have not received sufficient attention in the literature. We elaborate on these issues next.

First, most studies on virtual interfirm integration have been conducted in a domestic market setting (Mukhopadhyay and Kekre 2002). Scant empirical research has investigated virtual interfirm integration in cross-border exchange relationships. Although increased 
globalization has resulted in profuse inter-firm relationships across national borders, which makes IT enabled coordination more salient in this setting, understanding of antecedents and outcomes of virtual interfirm integration in the international customer-supplier context remains limited. While several scholars addressed this issue from an MNE perspective (e.g. Rangan and Sengul 2009), few have investigated the virtual interfirm integration behavior of suppliers.

Second, most previous studies have examined either the relationship between virtual interfirm integration and its antecedents, or the relationship between virtual interfirm integration and associated performance outcomes (Mukhopadhyay and Kekre 2002; Zaheer and Venkatraman 1994). Very few studies have attempted to model the complete picture of virtual interfirm integration through simultaneously examining drivers and performance implications. Addressing this issue is thus appropriate, because without building a comprehensive model of virtual interfirm integration and its link to performance, it is not possible to gain a full understanding of the condition under which virtual interfirm integration serves multinationals and their suppliers' coordination efforts in cross-border transactions.

Third, most prior studies have conceptualized virtual interfirm integration through adopting inter-organizational information systems (IOS) that focus more on the context of electronic data interchange (EDI) (Grover and Saeed 2007) to conduct operational tasks such as transactions, checking inventories, or output and process control between channel parties. However, technological innovation has resulted in contemporary IOS shifting from EDI toward more Internet-based, open standard IOS which incorporates functionalities such as collaborative forecasting, beyond the ones provided by traditional EDI (Zhu et al. 2006a). Hence, there is a need to conceptualize virtual interfirm integration as a multi-dimensional construct, which incorporates both electronic coordination and electronic collaboration.

Finally, the debate about the value of IT is still unresolved. Researchers have examined the value of IT applications in the inter-organizational context in general, and in supply chain relationships in particular (Sanders 2008, 2007). It is still not yet clear whether and how IT investments create value in international exchange relationships. In addition, while research argued environment may shape IT-performance relationships, IT value under environmental uncertainty is still an open issue (Melville et al. 2004; Wade and Hulland 2004). Thus, this research examines the contingency factors, including environmental volatility and communication culture in cross-border exchange relationships. 
The specific context relates to cross-cultural exchange relationships between MNEs and their suppliers. Drawing on the literature of transaction cost economics (Williamson 1975), the resource based view (Barney 1991), and international business, we develop and test a model that explains the driving forces and performance consequences of virtual interfirm integration in the international customer-supplier arrangements. Specifically, we conceptualize virtual interfirm integration in terms of coordination and collaborative arrangements via electronic media between suppliers and their international customers. These relationships between Taiwanese original equipment manufacturing (OEM)/original design manufacturing (ODM) suppliers and their MNE customers in the electronics industry provide the context of this investigation. This context is ideal for our study, because customers of Taiwanese OEM/ODM suppliers pursue coordination and collaboration and strongly rely on electronic media. Further, contracting supplier relationships with Taiwanese firm frequently involves asymmetric bargaining power, where MNE buyers usually have the upper hand. This context is thus ideal to examine how virtual interfirm integration can serve as an alternative mechanism to govern asymmetry in international customer-supplier relationships.

Finally, we contend that internal, inter-organizational, environmental, and cultural factors influence the virtual interfirm integration of suppliers with MNE customers. We consider innovativeness as a key dimension, internal to the organization. Trust is an interorganizational relationship dimension and in terms of environmental dimensions, we explicitly consider environmental volatility. In terms of cultural factors, we also consider the context of communication culture (Hall 1976). This is critically important to the context of virtual interfirm integration, since research has found communication culture to be an antecedent of virtual interfirm integration in international supplier-customer relationships (Ruey-Jer "Bryan" Jean et al. 2010). We contend that trust, innovativeness, context of communication culture and environmental volatility are associated with virtual interfirm integration, and investigate the direct and moderating link between virtual interfirm integration and relationship performance.

The remainder of this article is organized as follows. A conceptual model is developed to delineate the relationships among key constructs. Predictions regarding the antecedents, moderators, and consequences of virtual interfirm integration are offered. These hypotheses are tested empirically, and the results are presented. The paper concludes with a discussion of findings and directions for future research. 


\section{Background and conceptualization of virtual interfirm integration}

Virtual interfirm integration refers to a specific form of vertical-quasi integration achieved through implementing information systems (Wang et al. 2006). This research focuses on specific inter-organizational information systems: supply chain communication systems (SCCS). We define SCCS as an inter-organizational system shared by suppliers and international customers to carry out supply chain activities ranging from operational levels such as tracking orders, dealing with invoices and strategic levels such as collaborative demand planning and forecasting (Daekwan Kim et al. 2006). TCE contends that vertical integration is preferred over market exchange when the sum of transaction and production cost of market exchange exceeds those of hierarchy (Williamson 1975). However, vertical integration incurs significant drawbacks such as inflexible structure and unable to deal with changing circumstances.

Thus, virtual interfirm integration is an alternative governance and coordination mechanism, providing such benefits as reduced coordination cost and transaction risk, which vertical integration does not always provide (Wang et al. 2006; S. M. Kim and Mahoney 2006). Scholars have argued that IT-enabled integration is an effective governance mechanism that does not involve common ownership for exchange parties (Zaheer and Venkatraman 1994). Virtual interfirm integration constitutes a mechanism which relational governance could provide, because of its requirement that both exchange parties to invest in relationship-specific investments and mutual commitment (S. M. Kim and Mahoney 2006). Thus, it has been argued that virtual interfirm integration facilitates joint decision-making and collaborations in exchange relationships to give firms better capability in managing their channel relationships (Daekwan Kim et al. 2006).

Researchers have proposed varying approaches to operationalizing virtual interfirm integration (Wang et al. 2006; Zaheer and Venkatraman 1994). Earlier research only focuses on EDI use and integration as the proxy of virtual interfirm integration. Some recent studies have extended the conceptualization of virtual interfirm integration and operationalized it as a multidimensional construct. Subramani (2004) identified two patterns of IT use in virtual interfirm integration, including exploitation and exportation. Kim et al. (2005) referred to the specific domains of virtual interfirm integration for monitoring and for coordination.

Integrating the work of both Subramani (2004) and Kim et al. (2005), this study adopts two dimensions in conceptualizing virtual interfirm integration, coordination and collaboration, according to intentionality of use. 
Virtual interfirm integration for coordination includes conducting coordination and control channel activities such as checking inventory and product quality information through SCCS (K. K. Kim et al. 2005; Wang et al. 2006). Virtual interfirm integration for specific IOS such as EDI has been conducted by channel partners to support common operation execution and control, to help firms reduce coordination cost (Yamin and Sinkovics 2010, 2007). Virtual interfirm integration for collaboration refers to conducting collaborative planning, forecasting, and product design for partners via SCCS (M. Subramani 2004) (Daekwan Kim and Lee 2010). The internet-based open standard IOS such as Extensible Markup Language (XML) facilitates higher levels of virtual interfirm integration, which assists firms conduct more collaborative activities with their channel partners (Daekwan Kim et al. 2006).

\section{Conceptual framework and hypotheses}

Prior research on inter-organizational information system (IOS) adoption has extensively drawn on organizational, interorganizational, and environmental variables to examine the determinants of IOS adoption (e.g.Zhu et al. 2006b; Grover and Saeed 2007). Merging this stream of research with international/cross-cultural business literature, we offer the proposed conceptualization in Figure 1. This conceptualization identifies a set of important constructs in driving an supplier's virtual interfirm integration with MNE customers. Prior research has drawn extensively on TCE to examine the antecedents of virtual interfirm integration. According to TCE, virtual interfirm integration is an alternative coordination mechanism in governing exchange relationships, and argues that environmental uncertainty triggers firms to adopt hierarchical governance to reduce transactional hazards. Similarly, environmental volatility is a key driver for firms to implement virtual interfirm integration as an alternative form of hierarchical governance, which safeguards exchange relationships. In addition, TCE also treats trust as a crucial driver for governance decision of a firm. A trusting relationship creates an atmosphere that deters opportunism and helps develop long-term hierarchy like relationships. Thus, this study incorporated trust as a determinant of supplier virtual interfirm integration.

The resource-based view (Barney 1991) sees virtual interfirm integration as a key IT capability, which drives firm competitiveness (Wade and Hulland 2004). According to the RBV (Barney 1991), organizational capabilities are driven by firm internal strategic orientation (Zhou and Li 2010). Thus, we argue that innovativeness, a critical supplier orientation toward innovation (Hult et al. 2007), helps suppliers develop virtual interfirm 
integration in international exchange. Drawing from the theoretical development of international business and culture theories by Hall (1987), this study also included cultural factors unique to the international B2B context- the context of communication culture- into the conceptual framework. The context of communication culture highlights cultural communication, which could also affect the configuration of virtual interfirm integration for suppliers in relationships with MNE customers (Hall and Hall 1987).

These antecedents might affect the degree to which a supplier would employ virtual interfirm integration with an MNE customer. Interviews with supplier executives support the relevance of these constructs and their ability to comprehensively represent cross-cultural exchange relationships. These constructs are important to understand virtual interfirm integration in the international customer-supplier exchange; however, researchers have not adequately articulated a coherent explanation accounting for suppliers' virtual interfirm integration and associated performance outcomes. The RBV argues that virtual interfirm integration is a critical IT capability, which leverages advanced technologies in conducting key activities in the value chain to enhance firm competitive advantage. Thus, drawing on the RBV perspective, the proposed framework posits a direct link between virtual interfirm integration and performance in the international customer-supplier exchanges. The framework aims to determine the condition for the best virtual interfirm integration configuration, as a source of competitive advantage for the suppliers in international exchange relationships. Thus, following the arguments that environment may shape IT value (Dong et al. 2009), the current study investigates the moderating effects of environmental volatility and context of culture in the virtual interfirm integration-relationship performance link. The hypothesized linkages among these constructs are presented in Figure 1.

\section{Insert Figure 1 about here}

\subsection{Influence of communication cultures on virtual interfirm integration}

We draw from the work of Hall (1976) who articulated the characteristics of communication and classified culture into high versus low context culture. Hall (1976) argued that persons in a high-context culture (e.g. Japan, China) rely on the communication context more than in a low-context culture (e.g. US, Germany). Much of the supplier virtual interfirm communication is about exchanging order-sizes, forecasts, production outputs and 
stocks. While arguably the information will frequently be transmitted in some written form, we argue that depending on the cultural context, the dominant form of information transmission will change. That is, persons from a high-context culture obtain information mainly from their personal information network, while those from a low-context culture seek information from a research base or use information sources such as databases and the Internet. In this research we look at the emic-etic continuum of examining cultural phenomena primarily through an etic lens (Morris et al. 1999). ${ }^{1}$ The context of communication culture framework by Hall (1976) offers a unique way to classify various cultures according to the degree of embeddedness of communication context across countries. Given that the main power of virtual interfirm integration in the current study is to facilitate communication between exchange partners, the context of communication culture as a way to classify various communication cultures may be a critical determinant of virtual interfirm integration in international buyer-supplier relationships. However, only limited research has applied the Hall classification to investigate B2B innovation adoption, such as virtual interfirm integration in international buyer-supplier relationships.

Based on Hall's framework, this study argues that businesses in a high-context culture are likely to prefer in-person contacts to carry out every day B2B activities and such preference will reduce the need for IT-supported coordination. For example, during our field interviews with a key account managers in charge of Japanese customers, he indicated "Japanese customers are less likely to communicate and transfer business information via Internet and IT systems with us, they prefer to contact and communicate supply chain information via personal contacts". In contrast, businesses in a low-context culture may prefer to use codified information sources, obtained from electronic coordination and collaboration in international channel relationships. Consequently, this work follows Hall's classification of communication culture and hypothesizes the following effect of communication culture on virtual interfirm integration:

H1: With customers from low-context cultures, the extent to which the supplier is virtually integrated with its MNE customer will be greater.

1 We pursue the etic perspective in this work, as our research design is quantitative, survey-based and thus draws on scales which are concerned with the identification and assessment of universal attitudinal and behavioral concepts (Sinkovics and Holzmüller 2001). One reviewer highlights that that future work could seek to uncover emic aspects. 


\subsection{Innovativeness and virtual interfirm integration}

Prior studies have attempted to link organizational factors as determinants of IOS adoption (Zhu et al. 2006b). According to a recent review by Grover and Saeed (2007), organizational factors such as top management support, organizational slack, organizational readiness to accept new technology, and IT capability are considered import determinants of EDI use. An organization with enhanced innovative orientation is more likely to accept new technology. Consequently, this research focuses on innovativeness as a key determinant of a supplier's virtual interfirm integration with an MNE customer. Hult et al. (2004) conceptualize innovativeness as the capability of a firm to innovate by introducing new processes, products, or ideas into the organization. Innovativeness is among the most important organizational capabilities linked to firm success.

Innovativeness constitutes the key impetus for a supplier's virtual interfirm integration for the following reasons: First, innovative suppliers are more likely to develop better products and services for their customers in exchange relationships. Innovative suppliers perceive greater benefits provided by IT-enabled coordination and collaborations in international buyer-supplier relationships (Zhu et al. 2006a). For example, in the context of a global electronics supply chain, branded MNEs such as Dell and HP collaborate with Original Design Manufacturing (ODM) suppliers using B2B IT applications to develop products. Innovative suppliers are prone to advanced technology solutions to enhance their business process. Therefore, innovative firms are more likely to possess greater IT capability. Based on these arguments, we hypothesize,

H2: $\quad$ The greater a supplier's innovativeness is, the greater the level of virtual interfirm integration with the MNE customer.

\subsection{Impact of trust on virtual interfirm integration}

This study defined trust as the confidence exchange parties have for the reliability and integrity of the other (Zhang et al. 2003). The relational exchange theory views trust as a relational governance mechanism, helping deter opportunistic behavior because it lessens perceived vulnerability between partners (Cavusgil et al. 2004). Prior studies have identified trust as one of the most important inter-organizational factors for adopting IOS such as EDI (e.g. Zaheer and Venkatraman 1994; Hart and Saunders 1997; S. Lee and Lim 2005). Virtual interfirm integration involves sharing confidential information for coordination and collaboration between exchange parties. Therefore, it has potential risk to be misused as 
proprietary information by partners. Andraski and Haedicke (2003) note that the main concern of many suppliers with different buyers is the case where they share too much information. Then, when there is an unexpected high demand, those with greater bargaining power and information demand preferential treatment at the expense of others. Virtual interfirm integration may create a lock-in effect for the transaction party and an investing party may lose flexibility in exchange relationships. Given that international exchange relationships are more culturally diverse than domestic ones, exchange parties may be more skeptical and unwilling to use virtual interfirm integration as a coordination and collaboration mechanism to share confidential information. A significant imbalance in bargaining power may exist for suppliers with MNE customers. Thus, trust is particularly important for suppliers to electronically integrate with their MNE customers. A significant level of trust may help deter the risk of opportunistic behaviors by partners in international exchange relationships and thus facilitate virtual interfirm integration. Accordingly, we hypothesize,

H3: The higher trust a supplier has in the supplier-MNE customer relationship, the greater the level of virtual interfirm integration with the MNE customer.

\subsection{Effect of environmental volatility on virtual interfirm integration}

Environmental volatility refers to the extent to which an environment changes quickly (Skarmeas et al. 2002; Klein et al. 1990). In a competitive environment such as the global electronics industry, rapid fluctuations in demand and supply conditions aggregate a level of uncertainty because of difficulties associated with making accurate market forecast. The TCE literature suggests that one way to deal with environmental uncertainty is vertical integration with channel partners to reduce transaction cost (Klein et al. 1990). However, vertical integration incurs coordination cost and compromises firm flexibility in channel structures.

At the same time, virtual interfirm integration provides an alternative form of vertical integration without ownership. IT-enabled coordination and collaboration enhances information processing capabilities of the transaction parties and is a more efficient vertical coordination mechanism in coping with environmental uncertainty (Wang et al. 2006). Thus, researchers have argued that firms are more willing to electronically integrate with their partners to reduce transaction cost under environmental uncertainty (Wang et al. 2006).

However, a volatile physical and economic environment may present a barrier to the supplier to rely on electronic coordination and collaboration with the international customer. This is because of the difficulty associated with obtaining necessary and accurate information 
for effective electronic coordination, and in monitoring activities of the other partner. Under a volatile environment, product and market information changes quickly, thus making it more difficult to exchange timely information. An uncertain environment is likely to undermine the intention of a firm to conduct information-based collaboration such as CPFR due to the concerns of inaccurate forecast and planning. As a result, greater environmental volatility is associated with weaker electronic organization, such as electronic brokerage, to permit ongoing adaptations to changing market conditions (Grover and Saeed 2007). In an international exchange relationship where environmental uncertainty is exacerbated due to geographical and cultural distance between exchange partners (Skarmeas et al. 2002), eletctroniclly integrated may incur lock-in effect which reduce suppliers' adaptability. Hence, the supplier may not be willing to electronically integrate with the international customer to maintain its adaptability to have more international customers under a volatile environment.

Further, electronic integration requires transaction specific investments, for instance, suppliers need to invest in proprietary information systems and equipment. According to the TCE (M. R. Subramani and Venkatraman 2003), high transactional specific investment may incur concerns for appropriation and opportunism from the other exchange party, particularly in the asymmetric relationship in the supplier-MNE customer relationships. Accordingly, suppliers may be less willing to be electronically integrated with MNE customer under high environmentally volatility to avoid further exploitation or appropriation. Thus, we predict:

H4: $\quad$ The greater the environmental volatility a supplier faces, the less the supplier will virtually integrate with the MNE customer.

\subsection{Effect of virtual interfirm integration on relationship performance}

Relationship performance is defined as the extent to which a supplier's relationship with MNE customers is productive and rewarding (Skarmeas et al. 2002). Viewed as an effective form of governance, virtual interfirm integration provides better information processing capabilities to help suppliers with their operations and coordination processes with MNE customers. Therefore, it is expected that virtual interfirm integration enhances supplier performance by reducing transactions cost. Higher levels of virtual interfirm integration in IT-enabled collaborative activities such as CPFR, can serve the role of a relational contract, helping suppliers minimize transactional cost and creating governance value through selfenforcing agreements (S. M. Kim and Mahoney 2010). Kim and Mahoney (2006) further argue that virtual interfirm integration as a relationship specific investment enhances mutual commitment to the exchange relationship. Obviously, effective governance and relationship 
specific investment are valuable resources of firm competitive advantage in interorganizational relationships (Dyer and Singh 1998). In the case of OEM supplier-MNE customer relationships, supplier use of virtual interfirm integration can enhance firm reputations and IT capabilities, and thus help solidify existing arrangements while attracting more international business opportunities (Kang et al. 2009). Therefore, virtual interfirm integration can enhance the relationship performance of a firm in the international market.

The RBV literature investigated various attributes of IT resources and their contributions to firm performance (e.g., Wade and Hulland 2004). The view further contends that firms create value by combining heterogeneous resources that is economically valuable, difficult to imitate, or imperfectly mobile across firms (Barney 1991). In line with RBV, virtual interfirm integration is a more valuable outside-in IT resource to generate higher firm performance (Ruey-Jer "Bryan" Jean et al. 2008). Kim et al. (2006) empirically showed the positive relation of virtual interfirm integration to market performance in supply chain relationships. Thus, this study expects that virtual interfirm integration helps reap benefits for suppliers in relationships with their MNE customers.

H5: $\quad$ The greater a supplier is virtually integrated with an MNE customer, the greater the supplier relationship performance is.

\subsection{The moderating roles of environmental volatility and communication culture}

In our model, the effect of virtual interfirm integration on relationship performance in supplier-MNE customer relationships is expected to be influenced by environment variables in this study. Specifically, we examine two environment variables, environmental volatility and context of culture as potential moderators. In the strategy literature, the dynamic capabilities perspective argues that the value of a firm's resource and capabilities can be shaped by environmental dynamism and uncertainties (Teece et al. 1997). The dynamic capabilities perspective suggests that firms need to reconfigure resources and capabilities in order to respond to environmental changes and to sustain competitiveness.

In a volatile environment where prices and markets change rapidly, a supplier cannot be certain about the ability of each buyer in meeting their demand and price expectations. Thus, firms are likely to increase their adaptability through working with multiple customers in order to deal with unexpected market changes. Virtual interfirm integration under such conditions could restrict the suppliers' ability to coordinate within a specific dyad and forfeit their chances to locate multiple buyers and gather diverse market intelligence on prices 
(Grover and Saeed 2007). Hence, volatile environments may impede suppliers' capacity to benefit from virtual interfirm integration and in effect reduce relationship performance. Further, in volatile environments, customers may be motivated to further exploit supplier lock-in, specifically under conditions of asymmetric barging power relationships. Hence, it will reduce the chances that virtual interfirm integration serves as a safeguard mechanism of relationship performance enhancement. Accordingly, we argue that:

H6a: Virtual interfirm integration will have a stronger effect on relationship performance under low environmental volatility.

Communication culture (Hall 1976) shapes up the information sharing environment and may influence the effect of virtual interfirm integration on relationship performance. When the MNE customer is from high context culture, communication and the flow of information rely more on personal contacts and interactions (Hall 1976). In that case, information sharing is based mainly on physical contacts or is internalized in the personal domain (Donghoon Kim et al. 1998). In contrast, when the MNE customer is from a low context culture, the mass of information is vested in the explicit code. Low-context messages tend to be more context-free, relying more on explicit communications. According to the strategic fit perspective (Venkatraman 1989), a firm can increase its performance by achieving a fit between its strategies and environmental context. In line with this logic, when the MNE customer is from a low context culture may provide suppliers an informationsharing environment focusing more on explicit and electronic coordination. Thus, the effect of virtual interfirm integration on relationship performance is expected to be stronger when the MNE customer is from a low context culture.

H6b: Virtual interfirm integration will have a stronger effect on relationship performance when customers from low-context cultures.

\subsection{Control variables}

Prior studies have found many variables that affect virtual interfirm integration and relationship performance. In particular, Berry et al. (2010) highlight the potential role of distance in international buyer-seller relationship. That is, any gap expressed as a distance in various socio-economic conditions between the countries where business partners are from, may cause some misunderstanding and incorrect assessment of impacts of various firm strategies (Berry et al. 2010). Implying the unfamiliarity of the business environments in a foreign market by multinational firms, such cross-national differences that managers either perceive or recognize, play an important role in their operations in foreign markets (Berry et 
al. 2010). Recognizing this, we selected cultural distance, institutional distance, and global connectedness distance as factors that influence the nature of the supplier-MNE customer relationships. We also incorporated two country level control variables ${ }^{2}$ including country income and communication infrastructure into the model as factors that influence a firm's relational performance in addition to the selected cross-national difference variables as shown in Figure 1. We believe these country level social-economic variables are critical to control for in the study given this study explores interfirm communication between international buyer-sellers that shapes up relational performance. Furthermore, this study adopts relationship tenure as additional control variable as the length of relationship may imply the quality of relationship and, thus, relationship performance (Jap 2001). These factors have been examined in the literature in the context of international exchange relationships and virtual interfirm integration (Zhang et al. 2003; M. Subramani 2004). So, they are included in our study as control variables.

\section{Methodology}

\subsection{Research context and sample}

The unit of analysis in this study is the specific subcontracting relationship between Taiwanese suppliers and their international MNE customers in the electronics industry. The Taiwanese electronics industry contributes to the global industry structure and world economy significantly through the development of information technology (Dedrick and Kraemer 2007). To this end, an examination of the Taiwanese electronics industry captures industry leaders from the supplier perspective as well as contributing dominating MNE partners such as Intel, IBM, HP, and Dell. Most branded electronic companies outsource their product development and manufacturing to so-called original design manufacturers or ODMs, thus disintegrating their supply chain.

This study uses survey methodology. Key informants in this study are senior OEM/ODM account managers who are directly involved in international subcontracting relationships with branded firms and possess IT knowledge. The sampling frame comprises all electronic companies from the 2007 directory of the Top 5,000 Largest Firms in Taiwan, published by the China Credit Information Service Ltd. All firms in the database were contacted to assess their eligibility and locate appropriate informants for the study.

2 We thank one of our reviewers for this suggestion. 
The data collection followed a two-step approach. Qualitative interviews were initially conducted with 15 senior OEM/DOM account managers or directors to frame the context of the study and obtain conceptual input necessary to solidify construct development and contextualization of the survey instrument. Extra care was taken to counter-balance perspectives provided by MNE partners. Hence, two interviews were recorded with branded electronics MNE buyers. The second step undertook a large-scale survey. To maximize response from Taiwanese-based electronics companies, we followed the suggestion by $\mathrm{Yu}$ and Cooper (1983) to combine telephone and personal contact surveys. For a total of 1,056 potential participants who agreed to participate in the study in the initial telephone and e-mail surveys, a questionnaire was faxed or e-mailed. A total of 240 useable questionnaires were returned, resulting in an effective response rate of $22.72 \%(240 / 1,056)$. Table 1 presents respondent characteristics.

Non-response bias was assessed by classifying responses into two groups, early responses and late responses (Armstrong and Overton 1977). Independent t-tests on demographic variables such as revenue and employee number were performed. No significant difference was identified. This study also ran additional t-tests on key study variables such as electronic integration in the proposed conceptual model between these two groups. Again, no significant difference emerged. Hence, we conclude that non-response bias does not present a problem in this study (Armstrong and Overton 1977).

Insert Table 1 about here

\subsection{Measurement}

Multi-item scales and seven-point response formats were used to measure all variables. Fist, virtual interfirm integration of a supplier with the MNE customer was viewed as a higher-order construct and operationalized with electronic interfirm coordination and collaboration on the basis of the work by Kim et al. (2005) and Kim et al. (2006). Virtual interfirm coordination was assessed by employing a four-item scale, which captures the coordination and control aspects of virtual interfirm integration. Virtual interfirm collaboration was measured using three items focusing on the degree to which collaborative channel activities were conducted through information systems. This study adapted the scale for innovativeness of the supplier from Hurley and Hult (1998), addressing supplier abilities 
to introduce new technology to the industry and to the company, and the uniqueness and innovativeness of service. A four-item scale was adapted from Doney and Cannon (1997) to measure trust. These items measure supplier perception of the credibility and benevolence of MNE customers. For relationship performance, this study developed a scale consisting of five items based on the previous work of Selnes and Sallis (2003) and Kim et al (2006) and adapted to current study. Specifically, we ask the suppliers to identify their different aspects of performance resulting from relationship with their major international customer including sales growth, market share, product quality, current processes or creation of new processes, learning about customers and markets for our products.

Cultural distance in this study is operationalized as a composite score based on the commonly used procedure in the international business literature developed by Kogut and Singh (1988). The procedure calculates distance score for each MNE customer's country based on a variance-weighted average of the four dimensions of Hofstede, including individualism, uncertainty avoidance, masculinity, and power distance (Hofstede 1984). In terms of context of culture, Hall (1976) classifies countries into high or low-context cultures based on the way messages are communicated within a society. High- and low-context culture groups of the MNE customers were coded based on the Hall's classification. For environmental volatility, a four-item scale was adapted from Skarmeas et al. (2002), capturing the changeability of market shares, difficulty in monitoring trends, stability of industry volume, and accuracy of sales forecasts. Institutional distance is operationalized by calculating the distance between the supplier country and buyer country on all six dimensions including voice and accountability, political stability, government effectiveness, regulatory quality, rule of law, and control of corruption (Cuervo-Cazurra and Genc 2008) published by WorldBank. Global connectedness distance was calculated using the number Internet users per 1,000 across country published by World Development Indicators (Berry et al. 2010).

Finally, tenure of relationship in this study refers to the length of a supplier's relationship with the international buyer. We asked the respondents to indicate the time span of the supplier-buyer relationship in years and then the variable was log-transformed to alleviate univariate non-normalities and account for potential nonlinear effects (Wooldridge 2000). 


\section{Analysis and results}

\subsection{Common method bias}

Since all measures in this study were collected via a single questionnaire, common method bias is a potential threat to the study (Podsakoff and Organ 1986; Wu et al. 2006). We used a two-step approach to elucidate this issue. Firstly, the Harman one-factor test was used (Podsakoff and Organ 1986; Wu et al. 2006). A principal component analysis of all the items included in this study was performed. No dominant factor emerged (the first factor explains only $13 \%$ of the total variance), which provided no evidence for the presence of common method bias in this study. Secondly, we pursued a more rigorous approach to assess the extent to which common method bias affects the data analysis by conducting a test for potential common method bias using a hierarchical nested covariance structure model offered in the literature (e.g., Cote and Buckley 1987). The literature suggests that we estimate three models: trait only model (M2), method only model (M3), and trait and method model (M4). Table 2 reports the results of our estimations along with the results of testing for the presence of trait factors and for the presence of a method factor (D.-J. Lee et al. 2004). According to the results, variances from construct items (or traits) are significant. However, variances from the method present at $1 \%$ construct items are considered as in M2 and M4. This suggests that only an insignificant portion of the covariance originates from the method used in data collection. To further assess the extent to which such method variances are present in our data, we calculated the mean percentages of variance explained by the construct items and by the common method factor. The results show that the mean percentage of variance explained by the construct items is $67.1 \%$, while that of the common method factor is only $3.5 \%$, indicating that common method bias is minor (D.-J. Lee et al. 2004). Therefore, we conclude that common method bias does not pose a major threat to this study.

Insert Table 2 here

\subsection{Measurement model and construct validity}

Confirmatory factor analysis (CFA) was conducted using EQS for Windows 6.1 to evaluate the measurement model. The CFA model includes all five study constructs. To purify the measures, items with a loading less than .5 were eliminated to increase convergent validity. Item scales linked to more than one construct were also removed to improve 
discriminant validity. The purification process yielded at least three items for each construct. As Table 3 shows, the CFA model revealed an excellent fit with covariances provided by the dataset with $\chi^{2}=390.05$ on 194 d.f., NNFI $=.935, \mathrm{CFI}=.946$, and RMSEA $=.064$ (Bentler and Chou 1987).

Subsequently, the unidimensionality of constructs was evaluated by assessing convergent validity, discriminant validity, and construct reliability. According to the results, all items are significantly loaded on their corresponding factor $(\mathrm{p}<.01)$ and their loadings are greater than .5 as shown in Table 3, suggesting that all study constructs have an adequate level of convergent validity (Nunnally and Bernstein 1994). For discriminant validity, the average variance extracted (AVE) from each construct should be greater than its shared variances (Fornell and Larcker 1981). As reported in Table 4, the average variance extracted (AVE) for each construct ranged from .55 to .71 while the shared variances among constructs ranged from .02 to .66 , as reported in the upper triangle of Table 4. However, no shared variances were greater than the AVE of the respective construct. These results demonstrate a good level of discriminant validity between the study constructs (Fornell and Larcker 1981). Finally, the composite reliability of each construct and standardized parameters of measurement items are reported in Table 3. All composite reliabilities are greater than .86, far above the acceptable level of .7 suggested in the literature (Nunnally and Bernstein 1994).

Insert Tables $3 \& 4$ here

\subsection{Virtual interfirm integration as a second order construct}

Before estimating the structural model with virtual interfirm integration as a second order construct, we estimated another CFA with virtual interfirm integration specified as a second-order construct to assess its validity as a second-order construct. All other constructs remained the same as in the previous CFA. The results were $\chi^{2}=390.62$ with 196 d.f., NNFI $=.936, \mathrm{CFI}=.946$, and RMSEA $=.064$. While NNFI shows a minor fit improvement, most other fit indexes remained nearly the same. The chi-square difference confirms the two CFA models are not statistically different. To assess the model fit improvement between these nonnested models, we examined the reported CAIC index. To improve a non-nested model fit, the CAIC index should be decreased. According to the results, there was a fit improvement from the first order model $(\mathrm{CAIC}=-871.987)$ to the second order model $(\mathrm{CAIC}=-884.429)$. 
Subsequently, the validity of the second-order construct was assessed by first examining the loadings of the two dimensions of virtual interfirm integration for convergent validity. As shown in Table 5, the loadings were .70 for electronic coordination and .90 for electronic collaboration, indicating a good level of convergent validity. For discriminant validity, we examined the AVEs and shared variances. The shared variances ranged from .02 to .30 , which is much less than the AVE of .65 for virtual interfirm integration, showing a good level of discriminant validity for virtual interfirm integration as a second order construct. The composite reliability of virtual interfirm integration, the second order construct, was .79, which is greater than .70, suggested in the literature (Nunnally and Bernstein 1994). These results suggest good construct validity for virtual interfirm integration as a second-order construct.

Insert Table 5 here

\section{$5.4 \quad$ Structural model}

To test the hypotheses, the proposed model with all measurement items from the CFA model with virtual interfirm integration as a second order construct and two control variables (i.e., tenure of relationship and cultural distance for virtual interfirm integration and tenure of relationship for relational performance), was estimated using EQS for Windows 6.1. The results reveal an excellent model fit with the empirical covariances provided by the data with $\chi^{2}=588.391$ on 338 d.f., NNFI $=.943, \mathrm{CFI}=.953, \mathrm{RMSEA}=.055$. Based on the good fit of the structural model, the proposed hypotheses were tested.

Hypothesis 1 claimed that the difference in communication cultures (e.g., high vs. low context of cultures) would positively affect virtual interfirm integration. That is, if the MNE buyer is from a high context culture, virtual interfirm integration will be lower. The result supports hypothesis $1(\mathrm{~b}=-.117, \mathrm{p}<.05)$. Hypothesis 2 claimed that supplier innovativeness will positively affect virtual interfirm integration, which is supported by the result $(b=.322, p$ $<.01)$. Hypothesis 3 states that supplier trust in the international buyer will result in a high level of virtual interfirm integration. The results also support this hypothesis $(b=.220, p$ $<.01)$. The results further lend support for Hypothesis 4, for a negative effect of environmental turbulence on virtual interfirm integration $(b=-.149, p<.05)$. 
Regarding the effect of virtual interfirm integration on relationship performance, Hypothesis 5 states that virtual interfirm integration will positively influence relationship performance. The results provide support for this hypothesis $(b=.442, p<.01)$.

In terms of the control variables, we found the impact of tenure of relationship $(b=.006, p>.05)$, cultural distance $(b=-.044, p>.05)$, institutional distance $(b=.027, p>.05)$, and global connectedness distance $(b=.015, \mathrm{p}>.05)$ on virtual interfirm integration not significant. However, the effect of tenure of relationship $(b=.135, p<.05)$ on relational performance was significant while that of country income $(b=-.157, p>.05)$, country infrastructure $(b=.100, p>.05)$, cultural distance $(b=.081, p>.05)$, and connectedness distance $(b=.024, p>.05)$ on relational performance was not. Figure 2 summarizes these results.

For the moderating effects of environmental volatility and context of culture on the relationship between virtual interfirm integration and relational performance, we carried out ordinary least squares (OLS) regression analyses with relational performance as dependent variable and virtual interfirm integration as independent variable. Before adding the interaction terms to the regression model, the independent variable and two moderating variables are mean-centered to minimize the potential issue from multicollinearities between the independent variable and moderating variables (Aiken and West 1991). As reported in Table 6, the results support that environmental volatility moderates the effects of virtual interfirm integration on relational performance negatively ( $\mathrm{p}<.05$ ), which supports H6a. However, context of culture does not moderate the effects of virtual interfirm integration on relational performance significantly $(\mathrm{p}>.05)$. Thus, H6b is not supported.

Insert Table 6 and Figure 2 here

\section{Discussion and managerial implications}

The growth of international outsourcing activities has made managing interorganizational relationships critically important. Virtual interfirm integration via advanced IT has been increasingly adopted as an effective coordination mechanism in the supplier-MNE buyer relationships. Especially so in international exchange, because cross-border coordination is challenging due to the cultural and geographic separation between the MNE buyers and suppliers. Despite its managerial relevance, there is limited understanding of the role that virtual interfirm integration plays in international exchange relationships between 
suppliers and MNE buyers. This study adds to the contemporary knowledge-base on virtual interfirm integration by exploring how it develops in cross-cultural relationships and establishes a direct link between virtual interfirm integration and firm performance. Drawing from TCE and RBV, we investigate environmental volatility, innovativeness, and trust as key drivers of virtual interfirm integration. Based on the conceptualization of Hall (1976) regarding the context of culture, we examine the effect of communication culture on the degree of virtual interfirm integration in international exchange relationships and the performance outcome. In addition, this study examined the contingency conditions of virtual interfirm integration under environmental volatility and context of culture. The results of this study offer valuable implications for both theoretical development and managerial practice.

First, as a second order construct including electronic coordination and electronic collaboration, virtual interfirm integration in the supplier-MNE customer relationships has a positive effect on relationship performance for the supplier. The results demonstrate that virtual interfirm integration through technology-based coordination and collaboration channel activities can play a crucial role as an effective alternative governance mechanism. Supplying firms with a greater extent of virtual interfirm integration with their MNE customers can enhance information processing capabilities and reduce cross-border coordination costs, which ultimately improve performance outcome. This is consistent with TCE, which argues that an effective governance mechanism can enhance firm value in exchange relationships. This is also consistent with the RBV perspective of IT-business value, which argues that IT alone is not sufficient for enhancing firm performance (Devaraj et al. 2007; Cao and Dowlatshahi 2005). This view contends that only by integrating in specific firm activities such as coordination and collaboration in international exchange relationships can IT be a source of firm competitive advantage. Virtual interfirm integration in international exchange relationships can thus be an effective governance mechanism and serve as firm capability to create value for suppliers in international exchange relationships. Virtual interfirm integration reduces transaction costs and helps suppliers reap tangible rewards in sales growth, market share, and profitability, and even contributes to new products and learning about customers and markets for products. This result shed light on better understanding of how suppliers can effectively manage their asymmetry relationship with MNE buyers.

It is particularly worth noting that, building on dynamic capabilities perspective and strategic fit, this study tested the moderating effects of environmental volatility and context of culture on the link between virtual interfirm integration and relationship performance. This 
study contributes to the strategic IT literature by addressing the role of environment uncertainty in IT value creation, which to date remains an open issue (Dong et al. 2009). We found differential relationships of virtual interfirm integration to performance improvement contingent on environmental volatility. The result shows the effect of virtual interfirm integration on relationship performance is weaker under high environmental volatility. The theoretical explanation is that digitally enabled coordination may not be a good configuration in a high volatile environment. Virtual interfirm integration may incur certain inflexibility that may restrict suppliers' capabilities to adapt to changing and unpredictable environment.

However, the results of the antecedents of virtual interfirm integration in the suppliers-MNE buyer relationships show that communication culture has a significant effect on the degree of virtual interfirm integration. There has been limited empirical attention in the literature paid to the effect of communication culture on the degree of virtual interfirm integration in international exchange relationships. According to our results, a supplier from a high context culture will tend to be more reluctant to use inter-organizational information systems for coordination and collaboration activities with its MNE buyers from a high context culture. This finding verifies that communication culture between exchange parties in international exchange relationships, used in this study as an etic view, plays a crucial role in determining the degree of virtual interfirm integration. The context of culture framework by Hall (1976) as a type of etic approaches offers an important tool to understand and react to various communication cultures across countries.

This study did not find an effect of cultural distance on virtual interfirm integration. This is interesting and consistent with recent view in the literature on the potential misleading role of cultural distance in international business (Lew et al. 2016; Stahl and Tung 2015). For example, driven by globalization and a significant cross-pollination effect of culture (Ralston et al. 2008), global managers possess an increasing global mindset and similar culture value. Therefore, using a composite score of cultural distance in examining cross-border activities has become more challenging for international business studies (Tung 2008). Instead, this study finds that the use of communication culture as a measure of cultural difference between international transaction partners more appropriate in exploring virtual interfirm integration in international exchange relationships. The findings should not be surprising as Hall's (1976) framework more specifically addresses the differences in communication styles found across countries even though both Hosftede's cultural distance and Hall's (1976) framework offer another approach to the etic view from the communication culture point of view. That 
is, our finding suggests that global business managers should rely on a more activity-specific, yet culture-general, etic view based on the communication culture to the extent it is available to gain a direct benefit from their understanding of those etic views.

The results also demonstrate that a supplier's innovativeness can facilitate the development of virtual interfirm integration in international exchange relationships. We find evidence that innovativeness plays a crucial role in developing the IT-based interfirm interactions, which is conducive to higher firm performance. Innovativeness seems to have a signaling function to show the ability and strategic orientation of the supplier to engage in cross-border virtual business activities. This is consistent with prior literature, which proposes the crucial role of an innovative organizational culture in diffusing innovation (Hurley and Hult 1998). The results highlight a supplier's innovativeness helps not only stay ahead of competition as an organization internally but also develop more productive international exchange relationships with MNE customers externally.

The effect of trust on virtual interfirm integration is consistent with our expectation and thus reinforces the importance of developing healthy, trust-based relationships as key antecedents of virtual interfirm integration with MNE buyers. Trust serves as a key foundation for successful virtual interfirm integration between exchange partners, and is an inter-organizational tool to facilitate effective virtual coordination and collaboration between exchange partners.

In terms of environmental uncertainty, our results also show that environmental volatility presents a barrier to virtual interfirm integration between a supplier and its MNE customers. The cross-cultural context, which exacerbates the geographical and cultural distance of exchange partners, obviously implicates a reduced willingness to integrate business activities closely via electronic means. While it could potentially enhance exchange partners' responsiveness and flexibility in the cross-cultural relationship, environmental volatility seems to reduce the possibility of carrying out virtual interfirm activities.

From a managerial perspective, the findings suggest that managers of suppliers need to be aware of and take advantage of the potential benefits of investing in virtual interfirm integration, i.e. coordination and collaboration processes with their customers. The results show that suppliers can reap the benefits from the successful relationships with MNE customers through virtual interfirm integration. Virtual interfirm integration offers a good route for channeling internal mechanisms such as innovativeness, and inter-organizational 
mechanism like trust. Innovativeness and trust emerge as powerful antecedents of virtual interfirm integration and thus relationship performance eventually, and are prerequisites for implementing virtual connectedness. The effects of trust and innovativeness on relationship performance through the indirect linkage via virtual interfirm integration suggest a potent role of theses antecedents.

The negative association of environmental volatility with virtual interfirm integration suggests that unpredictable industry trends and competition remain a threat for suppliers, reducing their likelihood of engaging in virtual interfirm integration. As our results show, virtual interfirm integration features positive effects on performance. The context of communication culture incorporated in this study shows a significant negative effect on virtual interfirm integration, and highlights that communication culture plays an important role in the relationship exchange via electronic means. Thus, managers need to pay more attention to cultural context when implementing virtual interfirm integration in the international exchange.

\section{Limitations and directions for future research}

Study findings need to be considered against a set of limitations. First, when examining virtual interfirm integration and its associated antecedents and performance outcomes, this study considered the supplier's perspective. While there is a paucity of studies taking the supplier perspective and thus this viewpoint is an important contribution, it may be valuable to compare whether the findings are equally applicable from the perspective of the international customer. Dyadic perspectives in this context pose the specific challenge of asking respondents about the identity and contact details of their counterpart. We have been unsuccessful in eliciting appropriate response from our respondents, but future avenues are wide open for this area of research. Further, while our results support the direct relation ship between environmental volatility and virtual integration, the interaction effect is not supported. The relationship between environmental volatility and virtual integration may be more comlex than we propose. We acknowledge the limitation of this arguments and suggest further study to investigate some boundary conditions on the relationship between environmental volatility and virtual integration. Also, the specific context was a supplier sample in Taiwan, suggesting that an extension of the study to other countries is desirable. Furthermore, future studies may investigate various forms of electronic exchange such as the electronic market, and discuss its antecedents and performance implications in the 
international market. Another limitation of the present study relates to the difficulty in establishing casual relationships due to the cross-sectional nature of the data employed in testing the hypotheses. Although this study adopted several study variables from secondary data sources to overcome potential issues a study relying on a cross-sectional survey may have, there would still be a potential feedback loop from the dependent variable to some of the antecedents such as trust and/or virtual integration that the dataset this study used does not recognize. Future research may use longitudinal data and/or cross-lagged analysis to confirm our findings in this study. We hope this study will inspire further research to address issues pertaining to the critical role virtual interfirm integration plays in international buyerseller relationships.

\section{References}

Aiken, L., \& West, S. (1991). Multiple Regression : Testing and Interpreting Interactions: Sage Publications, Inc.

Andraski, J. C., \& Haedicke, J. (2003). CPFR: Time for the breakthrough? Supply Chain Management Review, 7(3), 54-58.

Armstrong, J. S., \& Overton, T. S. (1977). Estimating Nonresponse Bias in Mail Surveys. Journal of Marketing Research, 14(3), 396-402, doi:10.2307/3150783.

Barney, J. B. (1991). Firm Resources and Sustained Competitive Advantage. Journal of Management, 17(1), 99-121, doi:10.1177/014920639101700108.

Bentler, P. M., \& Chou, C.-P. (1987). Practical Issues in Structural Modeling. Sociological Methods Research, 16(1), 78-117, doi:10.1177/0049124187016001004.

Berry, H., Guillen, M. F., \& Zhou, N. (2010). An institutional approach to cross-national distance. Journal of International Business Studies, 41(9), 1460-1480, doi:10.1057/jibs.2010.28.

Birkinshaw, J., Toulan, O., \& Arnold, D. (2001). Global Account Management in Multinational Corporations: Theory and Evidence. Journal of International Business Studies, 32(2), 231-248, doi:10.1057/palgrave.jibs.8490950.

Buckley, P. J., \& Ghauri, P. N. (2004). Globalisation, economic geography and the strategy of multinational enterprises. Journal of International Business Studies, 35(2), 81-98, doi:10.1057/palgrave.jibs.8400076.

Cao, Q., \& Dowlatshahi, S. (2005). The impact of alignment between virtual enterprise and information technology on business performance in an agile manufacturing environment. Journal of Operations Management, 23(5), 531-550, doi:10.1016/j.jom.2004.10.010.

Cavusgil, S. T., Deligonul, S., \& Zhang, C. (2004). Curbing Foreign Distributor Opportunism: An Examination of Trust, Contracts, and the Legal Environment in International Channel Relationships. [Article]. Journal of International Marketing, 12(2), 7-27, doi:10.1509/jimk.12.2.7.32902.

Cote, J. A., \& Buckley, M. R. (1987). Estimating Trait, Method, and Error Variance: Generalizing Across 70 Construct Validation Studies. Journal of Marketing Research, 24(3), 315-318, doi:10.2307/3151642. 
Cuervo-Cazurra, A., \& Genc, M. (2008). Transforming disadvantages into advantages: developing-country MNEs in the least developed countries. Journal of International Business Studies, 39(6), 957-979, doi:10.1057/palgrave.jibs.8400390.

Dedrick, J., \& Kraemer, K. (2007). Globalization of Innovation: The Personal Computing Industry. Irvine CA: Personal Computing Industry Center.

Devaraj, S., Krajewski, L., \& Wei, J. C. (2007). Impact of eBusiness technologies on operational performance: The role of production information integration in the supply chain. Journal of Operations Management, 25(6), 1199-1216, doi:10.1016/j.jom.2007.01.002.

Doney, P. M., \& Cannon, J. P. (1997). An examination of the nature of trust in buyer-seller relationships. Journal of Marketing, 61(2), 35-51, doi:10.2307/1251829.

Dong, S., Xu, S. X., \& Zhu, K. X. (2009). Research Note--Information Technology in Supply Chains: The Value of IT-Enabled Resources Under Competition. Information Systems Research, 20(1), 18-32, doi:10.1287/isre.1080.0195.

Dyer, J. H., \& Singh, H. (1998). The relational view: Cooperative strategy and sources of interorganizational competitive advantage. Academy of Management Review, 23(4), 660-679, doi:10.5465/AMR.1998.1255632.

Ettlie, J. E., \& Pavlou, P. A. (2006). Technology-Based New Product Development Partnerships. Decision Sciences, 37(2), 117-147, doi:10.1111/j.15405915.2006.00119.x.

Fornell, C., \& Larcker, D. F. (1981). Evaluating Structural Equation Models with Unobservable Variables and Measurement Error. Journal of Marketing Research, 18(1), 39-50, doi:10.2307/3151312.

Grover, V., \& Saeed, K. A. (2007). The Impact of Product, Market, and Relationship Characteristics on Interorganizational System Integration in Manufacturer-Supplier Dyads. Journal of Management Information Systems, 23(4), 185-216, doi:10.2753/MIS0742-1222230409.

Hall, E. T. (1976). Beyond culture. Garden City, N.Y: Anchor Press.

Hall, E. T., \& Hall, M. R. (1987). Hidden differences: Doing business with the Japanese. Garden City, N.Y: Anchor Press/Doubleday.

Hart, P., \& Saunders, C. (1997). Power and trust: Critical factors in the adoption and use of electronic data interchange. Organization Science, 8(1), 23-42, doi:10.1287/orsc.8.1.23.

Hofstede, G. (1984). Culture's consequences: international differences in work-related values (Vol. 5, Cross-cultural research and methodology series). Newbury Park, CA.: Sage Publications.

Hult, G. T. M., Hurley, R. F., \& Knight, G. A. (2004). Innovativeness: Its antecedents and impact on business performance. Industrial Marketing Management, 33(5), 429-438, doi:10.1016/j.indmarman.2003.08.015.

Hult, G. T. M., Ketchen, D. J., \& Arrfelt, M. (2007). Strategic supply chain management: Improving performance through a culture of competitiveness and knowledge development. Strategic Management Journal, 28(10), 1035-1052, doi:10.1002/smj.627.

Hurley, R. F., \& Hult, G. T. M. (1998). Innovation, Market Orientation, and Organizational Learning: An Integration and Empirical Examination. Journal of Marketing, 62(3), 42-54, doi:10.2307/1251742.

Jap, S. D. (2001). "Pie sharing" in Complex Collaboration Contexts. Journal of Marketing Research, 38(1), 86 - 99, doi:10.1509/jmkr.38.1.86.18827.

Jean, R.-J. B., Sinkovics, R. R., \& Kim, D. (2008). Information technology and organizational performance within international business to business relationships: A 
review and an integrated conceptual framework. International Marketing Review, 25(5), 563-583, doi:10.1108/02651330810904099.

Jean, R.-J. B., Sinkovics, R. R., \& Kim, D. (2010). Drivers and Performance Outcomes of Relationship Learning for Suppliers in Cross-Border Customer-Supplier Relationships: The Role of Communication Culture. Journal of International Marketing, 18(1), 63-85, doi:10.1509/jimk.18.1.63.

Kang, M.-P., Mahoney, J. T., \& Tan, D. (2009). Why firms make unilateral investments specific to other firms: the case of OEM suppliers. Strategic Management Journal, 30(2), 117-135, doi:10.1002/smj.730.

Kim, D., Cavusgil, S. T., \& Calantone, R. J. (2006). Information System Innovations and Supply Chain Management: Channel Relationships and Firm Performance. Journal of the Academy of Marketing Science, 34(1), 40-54, doi:10.1177/0092070305281619.

Kim, D., \& Lee, R. P. (2010). Systems Collaboration and Strategic Collaboration: Their Impacts on Supply Chain Responsiveness and Market Performance. Decision Sciences, 41(4), 955-981, doi:10.1111/j.1540-5915.2010.00289.x.

Kim, D., Pan, Y., \& Park, H. S. (1998). High-versus low-Context culture: A comparison of Chinese, Korean, and American cultures. Psychology and Marketing, 15(6), 507-521, doi:10.1002/(sici)1520-6793(199809)15:6<507::aid-mar2>3.0.co;2-a.

Kim, K. K., Narayan, S. U., \& Kim, B. H. (2005). An Assessment of Electronic Information Transfer in B2B Supply-Channel Relationships. Journal of Management Information Systems, 22(3), 293-320, doi:10.2753/MIS0742-1222220310.

Kim, S. M., \& Mahoney, J. T. (2006). Mutual commitment to support exchange: relationspecific IT system as a substitute for managerial hierarchy. Strategic Management Journal, 27(5), 401-423.

Kim, S. M., \& Mahoney, J. T. (2010). Collaborative planning, forecasting and replenishment (CPFR) as a relational contract: an incomplete contracting perspective. International Journal of Learning and Intellectual Capital, 7(3-4), 403-428, doi:10.1504/IJLIC.2010.034377.

Klein, S., Frazier, G. L., \& Roth, V. J. (1990). A Transaction Cost Analysis Model of Channel Integration in International Markets. Journal of Marketing Research, 27(2), 196-208, doi: $10.2307 / 3172846$.

Kogut, B., \& Singh, H. (1988). The Effect of National Culture on The Choice of Entry Mode. Journal of International Business Studies, 19(3), 411-432, doi:10.1057/palgrave.jibs.8490394.

Lee, D.-J., Sirgy, M. J., Brown, J. R., \& Bird, M. M. (2004). Importers' Benevolence Toward Their Foreign Export Suppliers. Journal of the Academy of Marketing Science, 32(1), 32-48, doi:10.1177/0092070303254382.

Lee, S., \& Lim, G. G. (2005). The impact of partnership attributes on EDI implementation success. Information \& Management, 42(4), 503-516, doi:10.1016/j.im.2003.03.001.

Lew, Y. K., Sinkovics, R. R., Yamin, M., \& Khan, Z. (2016). Trans-specialization understanding in international technology alliances: the influence of cultural distance. Journal of International Business Studies, 47(5), 577-594, doi:10.1057/jibs.2016.10.

Melville, N., Kraemer, K., \& Gurbaxani, V. (2004). Review: Information Technology and Organizational Performance: An Integrative Model of IT Business Value. MIS Quarterly, 28(2), 283-322.

Morris, M. W., Leung, K., Ames, D., \& Lickel, B. (1999). Views from inside and outside: Integrating emic and etic insights about culture and justice judgment. Academy of Management Review, 24(4), 781-796, doi:10.5465/AMR.1999.2553253 
Mukhopadhyay, T., \& Kekre, S. (2002). Strategic and operational benefits of electronic integration in B2B procurement processes. Management Science, 48(10), 1301-1313, doi: $10.1287 / \mathrm{mnsc} .48 .10 .1301 .273$.

Nolan, P., Sutherland, D., \& Zhang, J. (2002). The Challenge of the Global Business Revolution. Contributions to Political Economy, 21(1), 91-110, doi:10.1093/cpe/21.1.91.

Nunnally, J. C., \& Bernstein, I. H. (1994). Psychometric Theory. New York: McGraw-Hill.

Podsakoff, P. M., \& Organ, D. W. (1986). Self-Reports in Organizational Research: Problems and Prospects. Journal of Management, 12(4), 531-544, doi:10.1177/014920638601200408.

Ralston, D. A., Holt, D. H., Terpstra, R. H., \& Kai-Cheng, Y. (2008). The impact of national culture and economic ideology on managerial work values: a study of the United States, Russia, Japan, and China. Journal of International Business Studies, 39(1), 826, doi:10.1057/palgrave.jibs.8400330.

Rangan, S., \& Sengul, M. (2009). Information technology and transnational integration: Theory and evidence on the evolution of the modern multinational enterprise. Journal of International Business Studies, 40(9), 1496-1514, doi:10.1057/jibs.2009.55.

Sanders, N. R. (2007). An empirical study of the impact of e-business technologies on organizational collaboration and performance. Journal of Operations Management, 25(6), 1332-1347, doi:10.1016/j.jom.2007.01.008.

Sanders, N. R. (2008). Pattern of information technology use: The impact on buyer-supplier coordination and performance. Journal of Operations Management, 26(3), 349-367, doi:10.1016/j.jom.2007.07.003.

Selnes, F., \& Sallis, J. (2003). Promoting relationship learning. Journal of Marketing, 67(3), 80-95, doi:10.1509/jmkg.67.3.80.18656.

Sinkovics, R. R., \& Holzmüller, H. H. (2001). National differences in materialism - Using alternative research strategies to explore the construct. Journal of International Consumer Marketing, 13(2), 103-134, doi:10.1300/J046v13n02_06.

Skarmeas, D., Katsikeas, C. S., \& Schlegelmilch, B. B. (2002). Drivers of Commitment and its Impact on Performance in Cross-Cultural Buyer-Seller Relationships: The Importers Perspective. Journal of International Business Studies, 33(4), 757-783, doi:10.1057/palgrave.jibs.8491043.

Stahl, G. K., \& Tung, R. L. (2015). Towards a more balanced treatment of culture in international business studies: The need for positive cross-cultural scholarship. Journal of International Business Studies, 46(4), 391-414, doi:10.1057/jibs.2014.68.

Subramani, M. (2004). How do suppliers benefit from information technology use in supply chain relationships? MIS Quarterly, 28(1), 45-73.

Subramani, M. R., \& Venkatraman, N. (2003). Safeguarding investments in asymmetric Iinterorganizational relationships: theory and evidence. Academy of Management Journal, 46(1), 46-62, doi:10.2307/30040675.

Teece, D. J., Pisano, G., \& Shuen, A. (1997). Dynamic capabilities and strategic management. Strategic Management Journal, 18(7), 509-533, doi:10.1002/(SICI)10970266(199708)18:7<509::AID-SMJ882>3.0.CO;2-Z.

Tung, R. L. (2008). The cross-cultural research imperative: the need to balance cross-national and intra-national diversity. Journal of International Business Studies, 39(1), 41-46, doi:10.1057/palgrave.jibs.8400331.

Venkatraman, N. (1989). The Concept of Fit in Strategy Research: Toward Verbal and Statistical Correspondence. The Academy of Management Review, 14(3), 423-444, doi:10.5465/AMR.1989.4279078. 
Wade, M., \& Hulland, J. (2004). Review: The resource-based view and information systems research: review, extension, and suggestions for future research. MIS Quarterly, 28(1), 107-142.

Wang, E. T. G., Tai, J. C. F., \& Wei, H.-L. (2006). A Virtual Integration Theory of Improved Supply-Chain Performance. Journal of Management Information Systems, 23(2), 4164, doi:10.2753/MIS0742-1222230203.

Williamson, O. E. (1975). Markets and Hierarchies: Analysis and Antitrust implications. New York: Free Press.

Wooldridge, J. M. (2000). Introductory econometrics: A modern approach: South-Western College Publishing.

Wu, F., Yeniyurt, S., Kim, D., \& Cavusgil, S. T. (2006). The impact of information technology on supply chain capabilities and firm performance: A resource-based view. Industrial Marketing Management, 35(4), 493-504, doi:10.1016/j.indmarman.2005.05.003.

Yamin, M., \& Sinkovics, R. R. (2007). ICT and MNE reorganisation: the paradox of control. Critical Perspectives on International Business, 3(4), 322-336, doi:10.1108/17422040710832577.

Yamin, M., \& Sinkovics, R. R. (2010). ICT deployment and resource-based power in multinational enterprises. Futures, 42(9), 952-959, doi:10.1016/j.futures.2010.08.027.

Yu, J., \& Cooper, H. (1983). A Quantitative Review of Research Design Effects on Response Rates to Questionnaires. Journal of Marketing Research, 20(1), 36-44, doi: $10.2307 / 3151410$.

Zaheer, A., \& Venkatraman, N. (1994). Determinants of electronic integration in the insurance industry: An empirical test. Management Science, 40(5), 549-557, doi:10.1287/mnsc.40.5.549.

Zhang, C., Cavusgil, S. T., \& Roath, A. S. (2003). Manufacturer governance of foreign distributor relationships: do relational norms enhance competitiveness in the export market? Journal of International Business Studies, 34(6), 550-566, doi:10.1057/palgrave.jibs.8400051.

Zhou, K. Z., \& Li, C. B. (2010). How strategic orientations influence the building of dynamic capability in emerging economies. Journal of Business Research, 63(3), 224-231, doi:10.1016/j.jbusres.2009.03.003.

Zhu, K., Kraemer, K. L., Gurbaxani, V., \& Xin Xu, S. (2006a). Migration to Open-Standard Interorganizational Systems: Network Effects, Switching Costs, and Path Dependency. MIS Quarterly, 30(Special Issue), 515-539, doi:10.2307/25148771.

Zhu, K., Kraemer, K. L., \& Xu, S. (2006b). The Process of Innovation Assimilation by Firms in Different Countries: A Technology Diffusion Perspective on E-Business. Management Science, 52(10), 1557-1576, doi:10.1287/mnsc.1050.0487. 
Figure 1: Proposed conceptualization of virtual interfirm integration in international supplier-customer relationships.

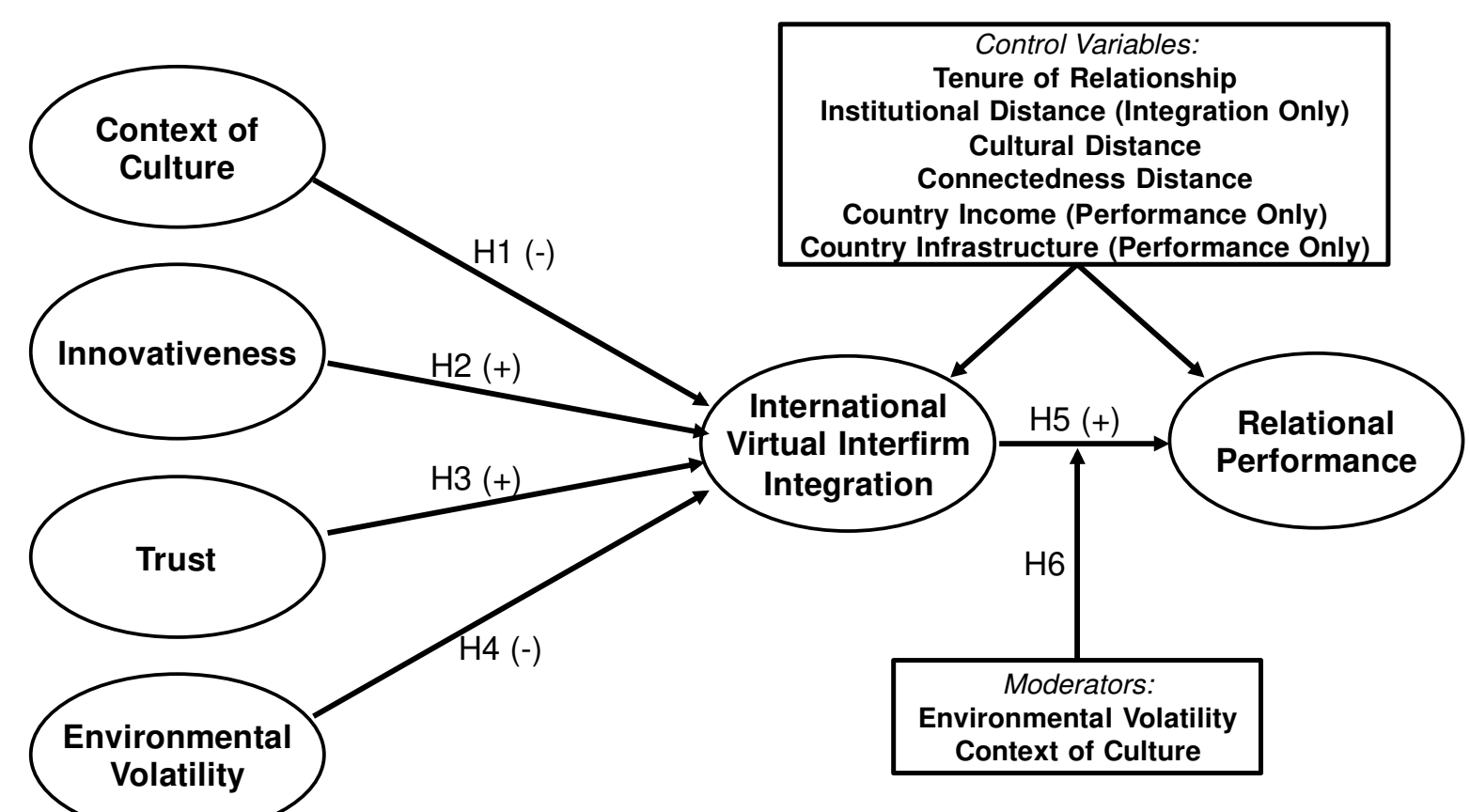


Table 1: Demographic characteristics of respondent firms $(n=240)$

\begin{tabular}{|ll|}
\hline Product Distribution & Percentage \\
\hline Communication Products & $12.1 \%$ \\
Systems & $6.3 \%$ \\
Computer Peripherals & $14.2 \%$ \\
Optoelectronics & $14.6 \%$ \\
Semiconductors & $15.8 \%$ \\
Computer Components & $37.1 \%$ \\
\hline \multicolumn{2}{|l}{} \\
\hline Employee Numbers & Percentage \\
\hline Less than 100 & $20.0 \%$ \\
$100-199$ & $21.7 \%$ \\
$200-499$ & $26.7 \%$ \\
$500-999$ & $13.3 \%$ \\
$1000-4999$ & $14.6 \%$ \\
$5000-9999$ & $1.7 \%$ \\
10000 and above & $2.1 \%$ \\
\hline
\end{tabular}

\begin{tabular}{|ll|}
\hline Sales Revenue & Percentage \\
\hline NT100M-NT500M (US \$3M) & $19.6 \%$ \\
NT501-NT1B & $15.8 \%$ \\
NT1B-NT5B & $39.2 \%$ \\
NT5B-NT10B & $7.5 \%$ \\
More than NT10B (US \$300M) & $17.9 \%$ \\
\hline
\end{tabular}


Table 2: Assessment of Common Method Bias

\begin{tabular}{|c|c|c|c|}
\hline Model & $\chi^{2}$ & df & $\mathrm{p}$ CFI NNFI SRMR \\
\hline M1: Null model & 3841.14 & 231 & $.000 \mathrm{n} / \mathrm{a} \quad \mathrm{n} / \mathrm{a} \quad \mathrm{n} / \mathrm{a}$ \\
\hline M2: Trait only model & 390.05 & 194 & $\begin{array}{llll}.000 & 935 & 946 & .049\end{array}$ \\
\hline M3: Method only model & 2352.41 & 209 & $\begin{array}{llll}.000 .344 & .406 & .169\end{array}$ \\
\hline M4: Trait and method model & 257.14 & 172 & $\begin{array}{llll}.000 & .968 & .976 & .036\end{array}$ \\
\hline Model Comparison & $\Delta \chi^{2}$ & $\Delta \mathrm{df}$ & Conclusion \\
\hline \multicolumn{4}{|c|}{ Testing for the presence of trait factors } \\
\hline M1-M2 & 3451.09 & 37 & $<.01 \quad \mathrm{M} 1>\mathrm{M} 2$ \\
\hline M3-M4 & 2095.27 & 37 & $<.01 \quad \mathrm{M} 3>\mathrm{M} 4$ \\
\hline \multicolumn{4}{|c|}{$\begin{array}{l}\text { Testing for the presence of a method } \\
\text { factor }\end{array}$} \\
\hline M1-M3 & 1488.73 & 22 & $<.01 \quad \mathrm{M} 1>\mathrm{M} 3$ \\
\hline M2-M4 & 132.91 & 22 & $>.01 \quad \mathrm{M} 2>\mathrm{M} 4$ \\
\hline
\end{tabular}


Table 3: Measures and composite reliabilities

\begin{tabular}{|c|c|c|}
\hline Constructs and Measures & & $\begin{array}{l}\text { Composite } \\
\text { Reliability }\end{array}$ \\
\hline $\begin{array}{l}\text { Innovativeness } \\
\text { Our firm's management actively seeks innovative ideas. } \\
\text { Innovation is readily accepted in program/ project management. } \\
\text { Technical innovation is readily accepted in our firm. }\end{array}$ & $\begin{array}{l}.87 \\
.91 \\
.69\end{array}$ & .87 \\
\hline $\begin{array}{l}\text { Trust } \\
\text { We believe the information that our international customer provides us. } \\
\text { Our international customer is genuinely concerned that our business succeeds. } \\
\text { When making important decisions, our international customer considers our } \\
\text { welfare as well as his own. } \\
\text { Our international customer is trustworthy. }\end{array}$ & $\begin{array}{l}.78 \\
.89 \\
.74 \\
.80\end{array}$ & .88 \\
\hline $\begin{array}{l}\text { Environmental Volatility } \\
\text { Sale forecasts in your business are quite inaccurate. } \\
\text { It is very difficult to monitor the trends in our industry } \\
\text { Sales volume in our industry is very volatile }\end{array}$ & $\begin{array}{l}.91 \\
.99 \\
.75\end{array}$ & .92 \\
\hline $\begin{array}{l}\text { Virtual interfirm integration-Coordination } \\
\text { Our international customer monitors our quality of product electronically. } \\
\text { We exchange product price and market information with our international } \\
\quad \text { customer electronically. } \\
\text { We and our international customer coordinate production plans with each other } \\
\text { electronically. } \\
\text { We and our international customer coordinate inventory levels with each other } \\
\text { electronically. }\end{array}$ & $\begin{array}{l}.70 \\
.73 \\
.91 \\
.93 \\
\end{array}$ & .89 \\
\hline $\begin{array}{l}\text { Virtual interfirm integration-Collaboration } \\
\text { Relying on our information system we collaborate on forecasting and planning } \\
\text { with our international customer. } \\
\text { Collaboration in demand forecasting and planning with our international customer } \\
\text { is always possible through our information system. } \\
\text { We collaborate with our international customer on new product design and } \\
\text { development through our information system. }\end{array}$ & $\begin{array}{l}.89 \\
.69\end{array}$ & .88 \\
\hline $\begin{array}{l}\text { Relationship Performance } \\
\text { Increased sales growth. } \\
\text { Increased market share. } \\
\text { Enhance product quality. } \\
\text { Improvements to current processes or creation of new processes } \\
\text { Learning about customers and markets for our products }\end{array}$ & $\begin{array}{l}.73 \\
.66 \\
.75 \\
.72 \\
.84\end{array}$ & .86 \\
\hline \multicolumn{3}{|l|}{$\begin{array}{l}\text { CFA Model Goodness of Fit Indexes: } \\
\text { Chi-square: } 390.05 \text { on } 194 \text { d.f., NNFI: .935, CFI: .946, \& RMSEA: .064 }\end{array}$} \\
\hline
\end{tabular}


Table 4: Intercorrelations and Shared Variances of Measures $(n=246)$

\begin{tabular}{ccccccc}
\hline & F1 & F2 & F3 & F4 & F5 & F6 \\
\hline Innovativeness (F1) & $\mathbf{. 6 9}$ & .13 & .02 & .09 & .16 & .25 \\
Trust (F2) & .36 & $\mathbf{. 6 5}$ & .07 & .07 & .12 & .44 \\
Environmental Turbulence (F3) & -.14 & -.26 & $\mathbf{. 7 9}$ & .04 & .06 & .05 \\
Virtual interfirm integration-Co (F4) & .30 & .26 & -.20 & $\mathbf{. 6 8}$ & .66 & .11 \\
Virtual interfirm integration-Coll (F5) & .40 & .34 & -.25 & .81 &. $\mathbf{7 1}$ & .15 \\
Relationship Performance (F6) & .50 & .66 & -.22 & .33 & .39 & $\mathbf{. 5 5}$ \\
\hline
\end{tabular}

Note: The correlations are in the lower triangle of the matrix. Shared variances are in the upper triangle of the matrix. The average variance extracted is in the diagonals.

Table 5: Virtual interfirm integration - Second Order Construct

\begin{tabular}{cc}
\hline First-Order Construct & Loadings \\
\hline Virtual Coordination & .70 \\
Virtual Collaboration & .90 \\
\hline Note: Average Variance Extracted $=.65 ;$ composite reliability $=79$.
\end{tabular}

Note: Average Variance Extracted $=.65$; composite reliability $=.79$.

Table 6: Moderating effect tests on relationship performance

\begin{tabular}{cccc}
\hline & Model 1 & Model 2 & Model 3 \\
\hline Virtual interfirm integration (VII) & $.33^{* *}$ & $.13^{*}$ & $.14^{*}$ \\
Innovativeness & & $.31^{* *}$ & $.30^{* *}$ \\
Trust & & $.24^{* *}$ & $.23^{* *}$ \\
Environmental Volatility (EV) & & -.11 & -.07 \\
Tenure of Relationship & & $.12^{* \mathrm{a}}$ & $.12^{* \mathrm{a}}$ \\
Context of Culture (CC) & $-.18^{* \mathrm{a}}$ & $-.19^{* \mathrm{a}}$ \\
Country Income & -.01 & -.02 \\
Communication Infrastructure & & -.20 & -.21 \\
Connectedness Distance & & .19 & .20 \\
Cultural Distance & .06 & .05 \\
VII x EV & & $-.11^{* \mathrm{a}}$ \\
VII x CC & & .04 \\
\hline R-Square & .111 & .334 \\
Adjusted R-Square & & .303 & .309 \\
\hline * $<$ <.05 & & \\
$* * \mathrm{p}<.01$ & & \\
${ }^{\mathrm{a}}$ One-tailed test & &
\end{tabular}


Figure 2: Role of virtual interfirm integration in the supplier-MNE buyer relationships

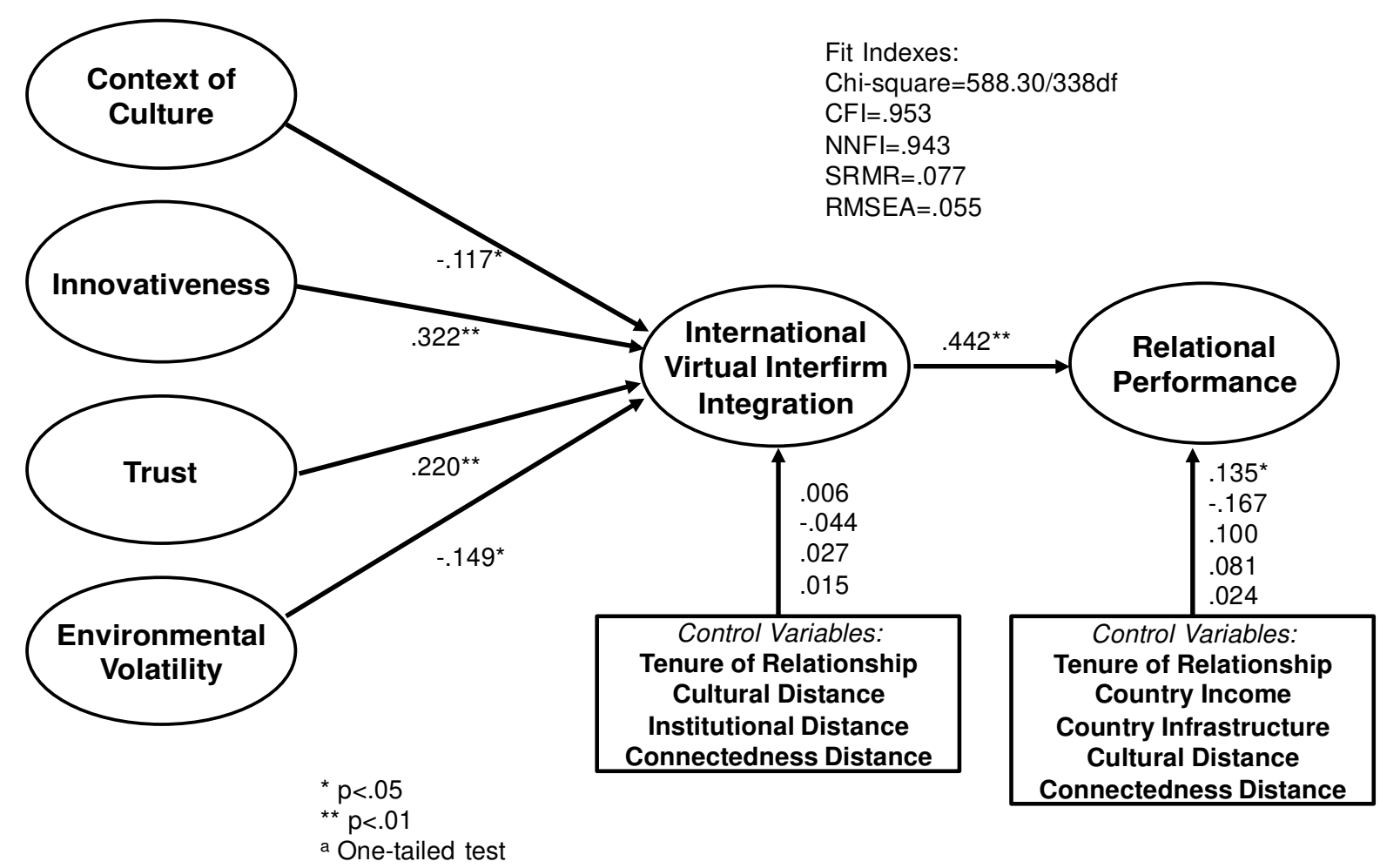

